\title{
Select Bibliography of Polish Folkloristics for the Period: 1990-1998
}

\author{
Anna Brzozowska-Krajka, Maria Curie-Sklodowska University, Lublin, Poland
}

The bibliography reveals trends typical of Polish folklore studies, and demonstrates various understandings of the term "folklore" by contemporary Polish folklorists. It especially reflects both textocentric and anthropocentric tendencies, as well as attempts at broadening the field of research. Popularizations of folklore and most literary transformations of folk motifs are excluded from this bibliography.

\section{PRIMARY SOURCES (TEXTS)}

Bery śmieszne i ucieszne. Humor ślqski, ed. D. Simonides, Warszawa: "Cyklady", 1992.

An anthology of Silesian humor, edited by an eminent Polish scholar, dealing with the folklore of Upper and Lower Silesia. These popular jokes are classified into groups according to their subjects: married life, miners' work, priests, doctors, peasants, etc.

Coby zgryzote poniechać. (Humoreski podhalańskie), ed. and intro. A. Brzozowska-Krajka, Kraków: Oficyna Podhalańska, 1997.

A selection of humorous tales from the Podhale region (in the West Carpathians). The book briefly presents the history of the highlanders' humorous tale in the main stages of its development: anonymous tales, semi-anonymous tales (from the turn of the nineteenth century), and comic stories written by contemporary authors.

Czubala, D., Wspólczesne legendy miejskie, Katowice: Uniwersytet Sląski, 1993.

The first edition of contemporary Polish urban legends: a broad selection of texts collected in Silesia. A comparative dimension is achieved by the inclusion of texts collected in Russia, Belarus, Ukraine and Mongolia. Monographic chapters deal with Polish, European and non-European research on urban legends, with methods of field research, and with other questions that model further investigations of this genre.

Czubala, D., Nasze mity wspólczesne, Katowice: Fundacja dla Wspierania Śląskiej Humanistyki, 1996.

An extensive anthology of Polish contemporary legends collected through local studies since the late 1970s. Its core consists of tales from Little Poland (Małopolska) and Silesia. It is the first publication of this kind in Poland. 
Dialekty polskie i folklor z różnuch regionów, ed. Z. Sobieszyński, Poznań: Uniwersytet A. Mickiewicza, 1991.

A dialectological work consisting of a book and an audio cassette. It contains a selection of folk texts (legends, rites, customs) from various regions of Poland, collected from 1960-65. The texts are published in a simplified phonetic transcription.

Dobkiewiczowa, K., Szkartatny rycerz. Podania i opowieści o zamkach ślaskich, Katowice: Wydawnictwo Sląsk, 1990.

A collection of literary adaptations of Silesian folk legends and tales concerning old castles of this region.

Gawedy z przeszlości Górnego Ślaska, ed. W. Korzeniowska, Opole: Instytut Śląski, 1990.

Historical folk tales from Upper Silesia, arranged according to subject and in chronological order - from the beginnings of the Polish state (the ninth century) to contemporary times.

Kadłubiec, K. D., Górniczy śmiech.(Komizm ludowy pogranicza czesko-polskiego), Wrocław: Polskie Towarzystwo Ludoznawcze, 1995. Series editor: C. Hernas, vol. 1.

A monograph of the humor of the Polish-Czech borderland, focusing on miners' tales - mainly from the second half of the nineteenth and the first half of the twentieth century. It also contains some fairly modern narratives. The book is divided into two parts. The first part constitutes a study of miners' humor, stressing the uniqueness of their mentality as well as the specificity of living in a borderland. The second part comprises comic tales told by various regional story-tellers.

Ksiega pieśni biesiadnuch, ed. E. Lagunionek, Białystok: Luk, 1994.

A selection of Polish popular songs and ballads. Most of them are anonymous folk songs, some are folk texts adapted by professional song and dance ensembles. The edition also contains songs from various epochs written by Polish poets and playwrights (e.g. M. Bałucki, K. Przerwa-Tetmajer, J. Tuwim), which have become popular throughout the ages. Some popular Russian ballads and songs are also included.

Ligoń, S., Bery i boiki ślaskie, Katowice: PiK, 1994.

The book contains both original folk jokes from Silesia and comic literary texts, e.g. dialogues, stories and sketches written by S. Ligoń for his radio programs.

Lysko, A. Demony i duszki bojszowskie. Opowieści ludowe z Górnego Slaska, Bojszowy: Stowarzyszenie Miłośników Ziemi Rodzinnej Korzyniec, 1992.

Tales from Silesia (the region of Pszczyna) collected from 1988-92. They deal with mysterious phantoms and unusual events from the world of Silesian folk beliefs, myths and demonic 
characters.

Lipowski, J., Roz widzieli straśne tognie ku Ciantorvi...Gawedy ludowe z Nawsia kolo Jablonkowa na Ślasku Cieszyńskim. Wroclaw: Tart (Studio Wydawniczo-Poligraficzne), 1992.

A collection of folk stories from the Polish-Czech borderland and a study of the Jabłonków dialect (the region of Cieszyn).

Lysiak, W., Dawny humor ludoury Pomorza Zachodniego, Międzychód: Eco, 1993.

A collection of humorous folk tales from Pomorze Zachodnie (the area of the western coast of the Baltic Sea) from the turn of the nineteenth century.

Lysiak, W., Mnisia Góra. Podania i bajki warciańsko-noteckiego miedzyrzecza, Międzychód: Eco, 1992.

A collection of traditional folk texts (legends, fairy tales) of the borderland of Great Poland (Wielkopolska) and Brandenburg (at the fork of the rivers Warta and Notec). The book presents beliefs, legends, superstitions and folk medicine common in this region at the turn of the nineteenth century.

Nowak, Z., Diabelski strzelec: Polskie baśnie i legendy, Warszawa: Nasza Ksiegarnia, 1991.

A substantial collection of fairy-tales and folk legends, many with little known plots, from all over Poland.

Qpowieści i legendy świetokrzuskie, ed. B: Wojewódzki, Foreword A. Krupska-Perek, Kielce: STON 2, 1996.

An anthology of various genres of folk prose from the Kielce region. The texts are arranged by subject: legends and explanations of natural and supernatural phenomena, history and human fate, traditions, beliefs, superstitions, folk medicine, etc. One section contains humorous tales. All texts are from the twentieth century (some are from the first half of the century, others are contemporary). Pieśni domowe i polne śpiewanki, ed. M. Brzuskowska, Zamość: Muzeum Zamojskie, 1990.

A collection of traditional (nineteenth century) folk songs from the Zamość region. It comprises songs of different genres, especially ballads and ritual songs (for weddings, harvests, etc). There are notes to each text with comments on symbolic meanings of particular words, expressions and images.

Podania legendy baśnie polskie, ed. A. Sójka, Poznań: Podsiedlik, Romanowski i Spółka, 1997.

A collection of ancient fairy tales and legends. Their folk and historical motifs are discussed by well-known Polish authors, e.g., J. I. Kraszewski, A. Oppman, E. Szelburg-Zarembina, et al. 
Polska ballada ludowa. Antologia, ed. E. Jaworska, Kraków: Polskie Wydawnictwo Muzyczne, 1991.

An anthology of Polish traditional folk ballads classified according to 43 plot types, e.g., "A lady kills her husband, "'Three roses on a grave," or "Ungrateful daughters." The texts are classified into thematic groups, e. g., murder, loss of virginity, infidelity, infanticide. The author's afterword characterizes the selected types of ballads as crime stories, didactic ballads (parables) and humorous songs. It also provides an overview of research on this genre.

Swirko, S., Rok placi - rok traci. Kalendarz przyslów i prognostyków rolniczych, Poznań: Wydawnictwo Poznańskie, 1990.

A selection of the most interesting proverbs concerning village life and the work of a farmer in his immediate natural environment (approximately 200 examples, from the fifteenth century to the present).

Turek, K, Koledu górnoślaskie. Wybór źródel i opracowanie, Katowice: Górnośląska Oficyna Wydawnicza, 1995.

A collection of Upper Silesian secular carols and Christmas carols, with notes. The texts come from printed and handwritten sources (fifteenth-nineteenth centuries) and from contemporary local records.

Zinkow, J., Krakowskie i jurajskie (wybór) podania, legendy, zwyczaje, 2nd ed., revised and enlarged, Kraków: Platan, 1994.

A selection of traditional folk tales and legends from Cracow and its environs (the so-called Jura Krakowsko-Częstochowska). It also contains folkloric traditions and customs still observed there but which have lost their original religious and ritual character.

\section{DICTIONARIES AND LEXICONS}

Kaczmarek, L., Skubalanka, T., Grabias, S., Stownik gwary studenckiej, Lublin: Uniwersytet Marii Curie-Skłodowskiej, 1994.

As a dictionary of Polish students' slang, this is a unique book of language humor. It is divided into thematic sections, e.g. man, external appearance, clothes, physiological functions, the campus, love, friends, etc.

Kowalski, P., Leksykon. Znaki świata. Omen, przesad, znaczenie, Warszawa: Państwowe Wydawnictwo Naukowe, 1998.

A lexicon of superstitions and omens rooted in Slavic mythology that reveals common elements in the traditional beliefs of various nations. Magic in Slavic mythology and culture is 
presented in the context of European and world folklore. The author's foreword discusses the characteristics of a folkloric and magical understanding of the world (i.e. space and its elements, nature and human activities).

Krzyżanowski, J., Madrei gtowie dość dwie slowie, Warszawa: Państwowy Instytut Wydawniczy, 1994.

A lexicon of Polish proverbs, sayings and quotations from the works of eminent men of letters compiled by a famous Polish folklorist and historian of literature. Each entry contains an interesting and witty, yet profound, factual analysis.

Stownik stereotypów i symboli ludowych, $t .1$ : Kosmos, ed. J. Bartmiński and S. Niebrzegowska, Lublin: Uniwersytet Marii Curie-Skłodowskiej, 1996.

A lexicon of folk stereotypes and symbols connected with cosmic space, the sky, stars, fire and stones. This is the first part of a seven-volume series of lexicons representing the ethnolinguistic approach to folklore favored by Jerzy Bartmiński and his disciples, co-authors of the edition. Ethnolinguistics interprets man, the world and natural phenomena in terms of archaic language stereotypes. The material recorded comes from the nineteenth and twentieth centuries, and was collected by dialectologists, folklorists and ethnographers. The lexicon is useful for comparative and historical studies of language and folklore.

Stępniak, K., Slownik taiemnvch gwar przestpeczych, in cooperation with Z. Podgórzec, London: Puls Publications Ltd., 1993.

A unique dictionary of the slang of prisoners, criminals and members of other folk groups.

\section{STUDIES}

Bartmiński, J., Folklor - jezyk - poetyka, Wrocław: Ossolineum, 1990.

The author understands folklore as oral and collective verbal production. He emphasizes some basic aspects of the language of folklore as a poetic interdialect. He analyzes the structure of folk songs and problems of style, (e.g., compactness and the ritualistic function of repetition). He also examines folk song texts in the context of lexical statistics.

Brzozowska-Krajka, A.,Symbolika dobowego cyklu powszedniego w polskim folklorze tradycyinym, Lublin: Uniwersytet Marii Curie-Skłodowskiej, 1994. English version:Polish Traditional Folklore. The Magic of Time, trans. W. Krajka, Boulder-Lublin-New York: East European Monographs, M. Curie-Skłodowska University, Columbia University Press, 1998.

This book discusses the temporal structures of peasant everyday life inherent in various verbal and nonverbal forms of Polish traditional folklore. The author's anthropocentric and interdisciplinary 
approach results in a comprehensive presentation of the examined phenomena through a complex analysis that considers the various codes making up the folk vision of man and the world. The English version of this study is the first substantial scholarly publication in the field of Polish folkloristics easily accessible to American, English-speaking and international scholars.

Dadak-Kozicka, J. K., Folklor sztukg życia. Uźródel antropologii muzyki, Warszawa: Instytut Sztuki PAN, 1996.

This book presents studies in Polish musical folklore from an anthropological perspective an area of study thus far not well developed in Poland. This is an attempt at formulating the anthropology of music in theoretical terms. The author applies the structuralist distinction between the spheres of langue and parole of a verbal text to musical folklore.

Dynak, W., Z dziejów polskiej pieśni lowieckiej, Wrocław: Wydawnictwo Uniwersytetu Wroclawskiego, 1991.

A monograph on Polish hunting songs from peasant and student folklore, both anonymous and attributed. The author analyzes both archaic texts from the nineteenth century and modern (twentieth century) examples.

Dynak, W., Lowy towcy i zwierzyna w przystowiach polskich, Wrocław: Towarzystwo Przyjacioł Polonistyki Wrocławskiej, 1993.

The author analyzes hunters' proverbs, discusses their jargon, and points out both their origin among the nobility and their structural features: didacticism, figurativeness and vividness. He also reconstructs the realm of hunters' superstitions and magical practices. Part of this discussion deals with the game and birds that most frequently appear in these proverbs.

Firlet, E. M., Smocza Jama na Wawelu. Historia, legenda, smoki, Kraków: Universitas, 1996.

The book deals with the history and the legend of the Dragon Den at Wawel Hill. It also discusses the role of the dragon motif in myths, fairy-tales and legends, as well as in works of art. The author primarily discusses Polish culture, especially the folklore of the Cracow region, but he also refers to the role of the same motifs in myths and works of art from other cultures.

Folklor-sacrum - religia, ed. J. Bartmiński, M. Jasińska-Wojtkowska, Lublin: Instytut Europy Srodkowo-Wschodniej, 1995.

Proceedings from an international scholarly conference dealing with the category of sacrum (the sacred) and with religious values in folklore. The book includes papers by folklorists from Poland, Russia, Bulgaria and Slovakia. They are divided into three parts: traditional beliefs, rites and cultic practices; the realm of folk songs, proverbs, fairy tales and prayers; and present-day folk and 
popular culture. The articles present the "poetics of sacrum " in Slavic folklore.

Folklorystyka. Dylematy i perspektywy, ed. D. Simonides, Opole: Uniwersytet Opolski, 1995.

Proceedings from a symposium of Polish and Slovak folklorists, representing both

philological (including ethnolinguistic) and anthropological approaches. They discuss the present state

of folkloristics (in Poland and in countries at a similar stage of development), possibilities of its growth, and its position among the humanities and in university education.

Folklorystyka 1. Zeszuty Naukowe, ed. P. Kowalski, Opole: Uniwersytet Opolski, 1995.

Folklorustyka 2. Zeszutu Naukowe, ed. T. Smolińska, Opole: Uniwersytet Opolski, 1996.

These Festschrifts edited by the Institute of Folkloristics, Opole University, present the scholarly interests of the Opole center of folklore studies. They concern not only Silesian folklore and its role in the lives of the contemporary inhabitants of this region but also the folklore of other parts of Poland, including written and oral forms of both traditional and modern folklore.

Folklorystyka. Materialy dla studentów filologii polskiej, part 1, ed. P. Kowalski, T. Smolińska, Opole: Wyższa Szkoła Pedagogiczna, 1992.

A selection of scholarly works by Polish folklorists, ethnologists and ethnolinguists, intended for students of Polish philology specializing in folkloristics.

Jaworska, E., Katalog polskiej ballady ludowej, Wroclaw: Ossolineum, 1990.

A catalog of ballad motifs and texts of similar genre and type. The classification contains more than $\mathbf{2 0 0 0}$ variants which come from published sources ranging from collections from the Romantic period to modern times. Ballads are placed into 11 thematic groups (e.g. murders, tragic events, reunions, etc.). The collection was created under the influence of The Catalog of Czech Folk Ballads compiled by M. Sramkova (Prague, 1970).

Kapehuś, H., Q turze zlotorogim. Szkice koledowe, Warszawa: Instytut Badań Literackich PAN, 1991.

A collection of essays on Polish carols, their poetics, cultural basis and regional variants.

Kasjan, J. M., Usta i pióro. Studia o literaturze ustnej i pisanej, Toruń: Uniwersytet M. Kopernika, 1994.

The book is a collection of essays on various genres of verbal folklore (fables, riddles, charms) and contains examples from contemporary folklore of the Chelmno region (Ziemia Chelmińska in northern Poland).

Kowalski, P., Samotność i wspólnota. Inskrypcje w przestrzeniach wspólczesnego życia, Opole: Wyższa Szkoła Pedagogiczna, 1993. 
This volume deals with church votive (prayer) books and children's graffiti. These two kinds of texts have completely different definitions of time, space and man. The author considers these two contemporaneous folkloric forms of inscriptions using the anthropology of everyday life.

Kowalski, P., Prośba do Pana Boga. Rzecz o gestach wotywnych, Wrocław: Towarzystwo Przyjaciół Polonistyki Wrocławskiej, 1994.

The author's research was based on contemporary entries in votive books - a new field of interest for anthropologically oriented folklorists. The analyzed material reveals imitations of traditional mentality and the special role of the category of sacrifice.

Lewandowski, A., Radkiewicz, J., Bocian w mowie i folklorze, Zielona Góra: Wyższa Szkoła Pedagogiczna, 1991.

A study of the role of the stork in Polish language and folklore, based on recordings from the nineteenth and twentieth centuries. The authors present various aspects of knowledge about storks (biological descriptions and systematizations are included).

Libera, L., Romantyczność i folklor. O twórczości Jacka Malczewskiego i Bolestawa Leśmiana, Poznań: Scientia, 1994.

A comparative study of folklorism in the artistic output of B. Leśmian (an eminent poet of Young Poland - Polish modernism) and J. Malczewski (a distinguished painter of the period). The anthor reconstructs the imagination and artistic visions of Malczewski and Leśmian taking into account the expressive function of folkloric and mythical traditions.

Lugowska, J., $W$ świecie ludowych opowiadań. Teksty. gatunki, intencje, Wrocław: Uniwersytet Wrocławski, 1993.

The book expands the traditional genre classification and typology of folktales by including the criterion of the creative intention of the peasant narrator. The following kinds of intention are distinguished: informative, moralistic (a warning against violating a commonly accepted system of values), comic (evoking laughter), compensatory, and deliberate frightening of a listener. The publication also reflects upon this folklore genre as a unit of classification and contains a textual grammar.

Lysiak, W., Ludowa wizja przeszlości: historyzm folkloru Wielkopolski, Poznań: Uniwersytet A Mickiewiczs, 1992.

This study is devoted to the image of the past immanent in and interpreted by the folklore of Great Poland (Wielkopolska). It reveals mechanisms for the mythologization of history and people's sensitivity to the temporal limits of imagination and of their knowledge. The scholarly thesis is 
supported by approximately. 200 folk texts, mainly from the region of Wielkopolska: legends, tales connected with names of places, historical tales, reports of eyewitnesses.

Lysiak, W., W kregu wielkopolskich demonów i przekonań niedemonicznych, Międzychód: Eco, 1993.

This book deals with traditional folktales from Great Poland (Wielkopolska) based on beliefs in demonic, half-demonic and nondemonic beings. Its rich folkloric records date back to the turn of the nineteenth century and come from the collections of O. Knoop, J.W. Malczewski and V. Schweda. Madyda, A., W poszukiwaniu jedności czlowieka i świata. Folklor w twórczości Stanislawa Vincenza, Toruń: Towarzystwo Naukowe w Toruniu, 1992.

The author turns our attention to the folklore of East Carpathian (Ukrainian) highlanders in the works of Stanisław Vincenz. This material was crucial to the creation of his tetralogy Na wysokiej poloninie. The author analyzes the highlanders' historical tales (legends), memoirs, anecdotes, songs, riddles, etc. as elements of the world presented in Vincenz's novels.

Niebrzegowska, S., Polski sennik ludowy, Lublin: Uniwersytet M. Curie-Skłodowskiej, 1996.

This work constitutes a linguistic description of the oral transmission of folk dreams as a genre of folklore. The material was gathered in various regions of Poland through questionnaires. Theoretical discussions are supplemented by a glossary of dream images.

Sielicki, F., Eolklor dzieciecy i mlodzieżowy na Wilejszczyńie w okresie miedzywojennym, Wrocław: Uniwersytet Wrocławski, 1992.

This monograph is a detailed presentation of the folklore of children and young people of the Wilno region (the author's native land). It contains texts which were popular between World Wars I and II: lullabies, nursery thymes, plays, fairytales, riddles, music and dances. The book is based on the reminiscences of the author and those of his informants from the same region. The texts were collected from 1971 to 1988.

Sielicki, F., Pieśni polskie śpiewane na Wilejszczyźnie w okresie miedzrwojennum. Wrocław: Uniwersytet Wroclawski, 1992.

A collection of Polish folk songs popular in the Wilno region between World Wars I and II: religious songs, humorous songs, children's songs, soldiers' songs, etc. Texts were taken from the reminiscences of the author and his informants, and were collected from 1979 to 1991.

Sielicki, F., Podania legendy, anegdoty i przystowia na Wilejszczyźnie w okresie miedzywojenmym, Wrocław: Uniwersytet Wroclawski, 1993.

The seventh part of a study devoted to the history, culture and folklore of the region of Wilno. 
It deals with folk prose: tales (especially humorous), legends, ghost stories, proverbs and sayings. The material was taken from reminiscences of the author and his informants, and was collected from the 1960 s to the present.

Sierociuk, J., Pieśń ludowa i gwara, Lublin: Krajowa Agencja Wydawnicza, 1990.

A dialectological study of the language of Polish peasant folk songs, based on recordings from the nineteenth and twentieth centuries from all over Poland. The author suggests the term "folklect" for the artistic language of folk song as distinct from "colloquial dialect", i.e. peasants' everyday speech.

Simonides, D., $Q$ wspólczesnych pamietnikach dzieci: Monografia folklorystyczna, Opole: Instytut Sląski, 1993.

This monograph about children's albums was based on intensive research and collecting. The author points to the early Renaissance origin of this genre and to its significant place in contemporary children's subculture. She characterizes its mode of existence as well as its rules of folk creation, i.e., their formulaic nature and anonymity.

Smolińska, T., Rodzina o sobie. Folklorystyezny aspekt rodzinnej tradycji kulturowej, Opole: Wyższa Szkola Pedagogiczna, 1992.

This book deals with the question of creation, function, transformation and disappearance of folklore within a family. It is based on sociological-ethnographic studies as well as local research, and deals with the structure of family life, family participation in folklore and with family folklore-creating situations. The aim of this work is to provide a model of folkloric family life.

Ślaskie uciechy i zabawy (materialy etnologiczno-folklorystyczne), ed. I. Bukowska-Floreńska, Bytom: Muzeum Górnośląskie, 1991.

A collection of articles about the main categories of play and humour in Silesian ritual and nonritual folklore of adults and children.

Turek, K., Ludowe zwyczaje, obrzedy i pieśni pogrzebowe na Górnym Ślasku, Katowice: Uniwersytet Sląski, 1993.

This study is devoted to funeral rites in Upper Silesia, especially funeral songs, and is based on both traditional and modern records.

Wężowicz-Ziółkowska, D., Milość ludowa. Wzory milości wieśniaczej w polskiej pieśni ludowej XVIIL-XX wieku, Wrocław: Polskie Towarzystwo Ludoznawcze, 1991.

A monograph on love in Polish traditional folk songs from the eighteenth to the twentieth centuries. The author examines various patterns of love and attitudes toward human sexuality in the 
culture of Polish peasants and in their ballads and songs, which are analyzed from a structural point of view. The attitudes to love revealed in these folk texts vary from frivolous, jocular or even obscene to the tragedy of unfulfilled desire. The songs present youthful and romantic feelings ranging from marital affection to sinful and illicit love.

W krequ badań nad folklorem. Materiahy pokonferencyine w dziesieciolecie śmierci Franciszka $\underline{\text { Kotuli }}$ ed. A. Kopoczek, K. Ruszel, Rzeszów: Wyższa Szkoła Pedagogiczna, 1995.

A collection of articles concerning well-known collectors of folklore from Eastern Little Poland (Małopolska): F. Kotula, Z. Wierzchowski, L. Magierski, B. Gustawicz. The volume also contains studies of the musical folklore of this region.

Wszustek krag ziemski. Antropologia, historia, literatura, works dedicated to Professor Czestaw Hernas, ed. P. Kowalski, Wroclaw: Uniwersytet Wrocławski, 1998.

The essays in this volume are dedicated to Professor Czesław Hernas, who was a pre-eminent Polish folklorist and a specialist in old Polish literature. They cover rules of encoding meanings in folklore, the identity of a folkloric text, various relationships between belles-lettres and popular literature, and studies of individual folklore genres (beggar's songs, lullabies, and jokes).

Zlatanova-Strenk, N., Rodowody. Idea wspólnoty w przekazach rodowodowych (na wybramym materiale slowiańskim), Warszawa: Uniwersytet Warszawski, 1992.

This book discusses the sense of community in genealogical texts from selected Slavic materials. It views genealogy as a cultural phenomenon -- a complex image reflecting various aspects of a sense of community. The study offers some methodological suggestions for the sociological research of group consciousness. The theory of genealogy is the author's main field of interest. The book demonstrates the potential of a pragmatic approach to diverse forms of genealogical knowledge and stresses the importance of folklore texts as family saga. The study calls for further research into various genealogical texts.

Zzagadnień polskiej kultury muzycznej. Studia folklorystyczne, ed. A. Dygacz, Katowice: Uniwersytet Sląski, 1994.

This book presents research on musical folklore from Lower Silesia, Upper Silesia and Cieszyn Silesia and miners' folklore, as well as Polish and Czech songs. Analogies between problems of origin and interethnic problems are emphasized.

(Translated by Agnes Monies-Mizera) 